\title{
Comparative investigation of the influence of kaolin and dolomite on the properties of polyurethane foam
}

\author{
Joseph Ajibade Omotoyinbo ${ }^{1}$, Isiaka Oluwole Oladele ${ }^{1,3, a,},{ }^{*}$. Jamiu Mosebolatan Jabar $^{2}$, Joseph Olatunde Borode ${ }^{1}$, \\ Kenneth Kanayo Alaneme ${ }^{1,3}$, Akeem Damilola Akinwekomi ${ }^{1}$ (D), Samuel Ranti Oke ${ }^{1,3, a,{ }^{*}}$, Taiwo Fisayo Omotosho ${ }^{1}$, \\ and Lawrence Ojo Saliu ${ }^{1}$ \\ ${ }^{1}$ Metallurgical and Materials Engineering Department, Federal University of Technology, PMB, 704, Akure, Ondo State, Nigeria \\ 2 Industrial Chemistry Department, Federal University of Technology, PMB, 704, Akure, Ondo State, Nigeria \\ 3 Center for Nanomechanics and Tribocorrosion, School of Metallurgy, Chemical and Mining Engineering, University \\ of Johannesburg, Johannesburg, South Africa
}

Received: 4 June 2021 / Accepted: 27 September 2021

\begin{abstract}
This work investigates the influence of kaolin and dolomite on the properties of polyurethane foam. The selected fillers were pulverized and sieved to obtained $<90 \mu \mathrm{m}$ that were used as reinforcements in the polyurethane matrix in a randomly dispersed mode. The matrix constituents were mixed in the same ratio while fillers were introduced via a one-shot system approach in predetermined proportions of 3-7 wt.\%. The work was carried out to identify optimum fillers to be utilized in the production of polyurethane rigid foams given the effect of the fillers on the physical, mechanical, and chemical properties of the foam. FTIR, XRF, and SEM and mechanical property tests were carried out on the filled polyurethane foam. The presence of the fillers in the foam showed a rupture in the structure of the foams with the cells having similar arrangements. The addition of dolomite and Kaolin degrades the sulfonic acid groups and promoted the appearance of Si-O stretching vibration band. The density, hardness, flexural and compressive strengths of the polyurethane foam were enhanced with the the addition of dolomite and kaolin particles.
\end{abstract}

Keywords: Polyurethane foam / dolomite / kaolin / mechanical properties

\section{Introduction}

The human world so revolves around comfort and luxury. Polyurethane foam which can be rigid, flexible, or semirigid is a versatile material that came into existence as a result of the chemical reaction between the functional group of isocyanate, and the polyhydroxyl group, which is polyol help to fulfill these desires. Rigid polyurethane foams (RPUFs) are expanded materials and formed through the addition of several processes - polymerization, expansion, gelling, and blowing [1,2]. RPUFs are highly cross-linked, three-dimensional polymers with closed-cell structures and account for about $29 \%$ of all polyurethane (PU) production $[3,4]$.

As a result of their outstanding mechanical properties, excellent thermal-insulating properties, low apparent density, and high resistance to weather conditions; they are widely used in diverse industries such as

\footnotetext{
${ }^{a}$ Samuel Ranti Oke, and Isiaka Oluwole Oladele contributed equally.

* e-mail: sroke@futa.edu.ng; iooladele@futa.edu.ng
}

the automobile, marine, civil, packaging, and furniture industries $[2,5]$. Their major application purposes are for thermal insulation, acoustic, shock-absorption, sound absorption, buoyancy, and floating applications [6]. RPUFs have become one of the most diverse and widely used materials with a continuously increasing global market. The total annual production of polyurethanes around the globe is about 8 million tons per year and is increasing $4-5 \%$ yearly [4] while the value of the global RPUF market amounts to 401 billion dollars in 2015 and is expected to triple in 2020 [7].

For RPUFs to progressively suit different application requirements for various industries in the future, there is the need to improve the mechanical and thermal properties of the foams while also drastically reducing their health [8] and environmental impact in terms of waste and toxicity [9-11]. Different studies have shown that the properties of RPUFs can be enhanced significantly by the use of different filler materials added in a specified proportion [12-18]. Nazim [19] studied the influence of the addition of kaolin on thermal conductivity and decomposition of polyurethane foams and reported that kaolin addition increased 
the thermal conductivities and enhance the thermal stability of rigid polyurethane foams. The study was however limited to thermal conductivity and decomposition of polyurethane foams. The microstructure and mechanical properties were not studied.

To further identify filler materials that are capable of effectively improving the foam properties, this research work was carried out to investigate the effect of dolomite and kaolin particle addition on the properties of rigid polyurethane foams. The influence of these fillers on the morphology (SEM analysis, XRF analysis, and FTIR analysis) and mechanical properties (hardness test, compressive test, and flexural test) of the polyurethane foams was evaluated.

\section{Materials and methods}

\subsection{Starting materials and processing of the foams}

The foam material consists of two-part polyurethane foam precursors in the form of liquid having a density of $240 \mathrm{~kg} / \mathrm{m}^{3}$ supplied by a Chemical and Allied Company in Lagos, Nigeria. Part-A is a polyo and part-B is an isocyanate polymer. Dolomite and kaolin particles are chosen as filler materials.

Ball mill was used to pulverize the fillers into powder form after which they were sieved to obtain particle sizes $<90 \mu \mathrm{m}$ that was used. About $60 \mathrm{~g}$ each of components $\mathrm{A}$ and $\mathrm{B}$ were mixed with variable proportions of dolomite and kaolin $(3,5$, and 7 wt.\%) to develop their respective foams. Since both components A and B were already preblended with all the required additives, the unfilled RPUF was synthesized by mechanically stirring both components together in equal proportions of $60 \mathrm{~g}$ for few seconds before being poured into the mold. This was done to obtain the control sample for comparison with the filled foams. For the kaolin and dolomite filled foams, they were produced by a two-step process $[2,3]$. For the first step process, each of the filler was added separately in 3,5 , and 7 wt. $\%$, respectively to component $\mathrm{A}$ and they were thoroughly mixed by mechanical stirring. For the second step process, component $\mathrm{B}$ was added to the existing mixture (component $\mathrm{A}$ and the filler) and were all properly mixed by mechanical stirring. On rising, each mixture was poured into an open mold to produce a defined shape and to allow for free foaming in the vertical direction. The foams were demolded after $30 \mathrm{~min}$ and were allowed to cure at room temperature for 24 hours [20]. Afterward, samples were cut into the appropriate shapes and sizes before the different required property tests were carried out.

\subsection{Characterisation of the processed foam}

Microstructural analysis of the unfilled and dolomite/ kaolin filled polyurethane foams was done using field emission scanning electronic microscope (JEOL JSM-760 $0 \mathrm{~F}$ ) equipped with energy dispersive X-ray spectroscopy (EDS). An FT-IR spectrometer (Infrared spectrometer Varian 660 MidIR Dual MCT/DTGS Bundle with ATR) was used to confirm the chemical structure of all samples. Before analysis, the samples were dried in an auto-desiccator for 24 hours. Samples were directly applied to a diamante crystal of ATR and resulting spectra of them were corrected for background air absorbance. Potassium bromide $(\mathrm{KBr})$ disks were prepared from powdered samples mixed with dry $\mathrm{KBr}$ in the ratio of $1: 100$. The spectra were recorded in a transmittance mode from 4000 to $400 \mathrm{~cm}^{-1}$ at a resolution of $4 \mathrm{~cm}^{-1}$. The infrared spectrum was Fourier transformed and recorded in the absorption mode.

\subsection{Mechanical property testing of the polyurethane foams}

Hardness test was conducted on the samples using a Shore D hardness tester in accordance with ASTM D2240-00 [21]. The samples were placed in the microhardness tester and indented. Four repeat tests were carried out on the samples to ensure reliability of the data generated.

Compression tests was done on the samples to obtain their compressive strength. The samples were cut in the shape of a cube of dimensions $30 \times 30 \times 30 \mathrm{~cm}$ and were subjected to an automated Universal testing machine of model 3369 INSTRON running on a blue hill two software, with working principle of finite difference method, the raw data were obtained and the stress-strain relationship established. The test was carried out on each sample with two representatives sectioned from each foam sample [22].

Three points bending test was used to evaluate the flexural property of the samples. Universal testing machine series 3369 model was used to carry out the flexural test in accordance to ASTM D790-03 standard [23]. A sample cut into $150 \times 50 \times 5 \mathrm{~mm}$ was placed in grip of the machine and was stretch at a test speed of $5 \mathrm{~mm} / \mathrm{min}$ over a span of $65.00 \mathrm{~mm}$. Three samples were tested for each composition and the average value was used as the representative values.

The density of the foams was calculated by cutting a cube of $3 \mathrm{~cm}$ from the whole sample, serving as a representative for the whole sample. They were weighed and their volume calculated with both result in place (mass and volume of the sectioned sample) the densities were calculated using equation (1).

$$
\operatorname{Density}\left(\mathrm{g} / \mathrm{cm}^{3}\right)=\text { Mass } / \text { Volume }
$$

\section{Results and discussion}

\subsection{Microstructural characterization of filled and unfilled polyurethane foam}

The structure and cell sizes of the unfilled polyurethane, dolomite and kaolin filled forms is shown in Figure $1 \mathrm{a}-\mathrm{c}$. The foams are closed cells with their average cell sizes ranging between 100 and $200 \mu \mathrm{m}$. The presence of the fillers in the foam showed a rupture in the structure of the foams with the cells not being uniform. The dolomite and kaolin spheres are distributed uniformly in the polyurethane matrix. The interface of the foam and particles is continuous with the particle surface having a high degree 

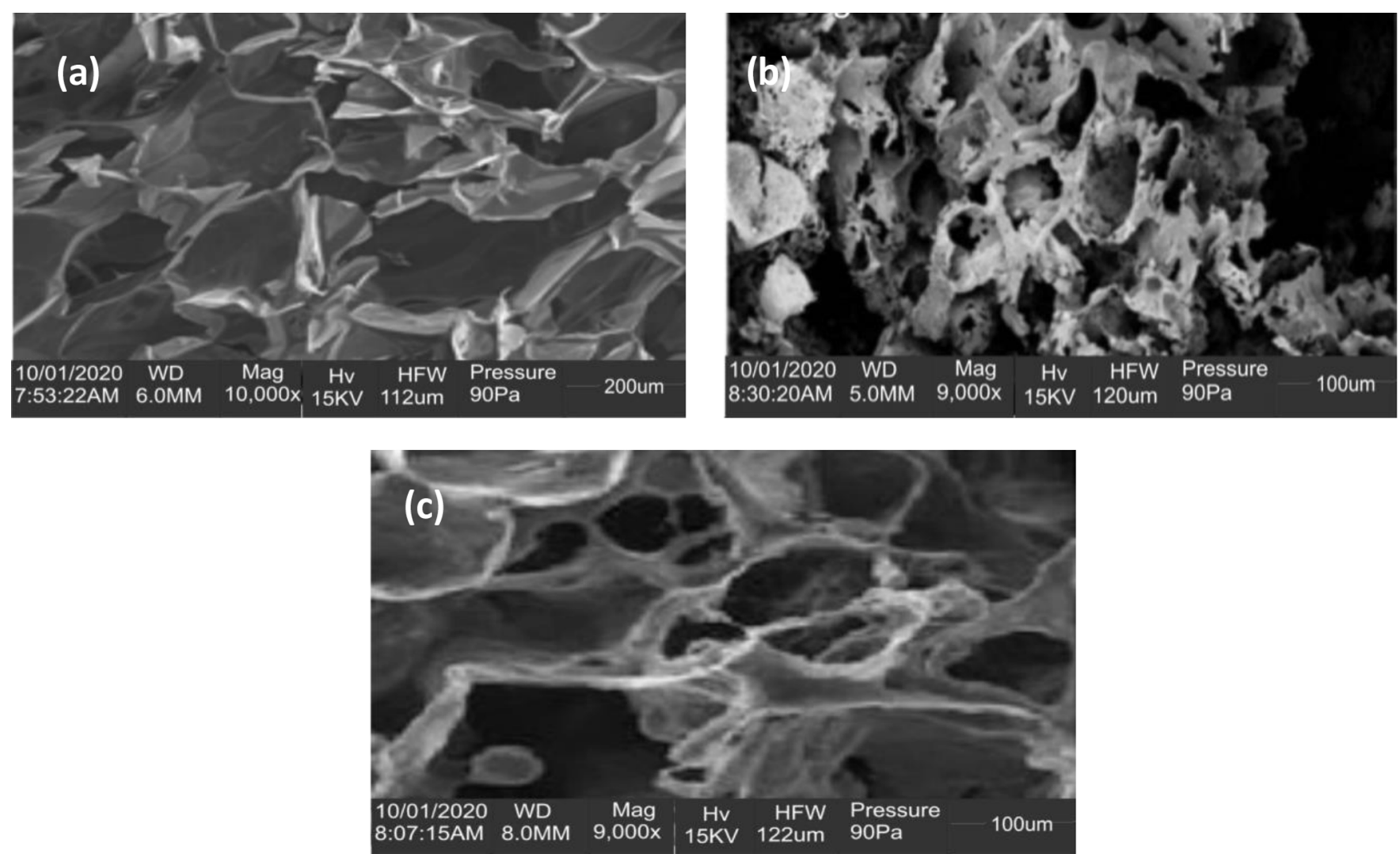

Fig. 1. SEM micrographs of samples (a) unfilled polyurethane foam (b) dolomite filled polyurethane foam (c) kaolin filled polyurethane foam.

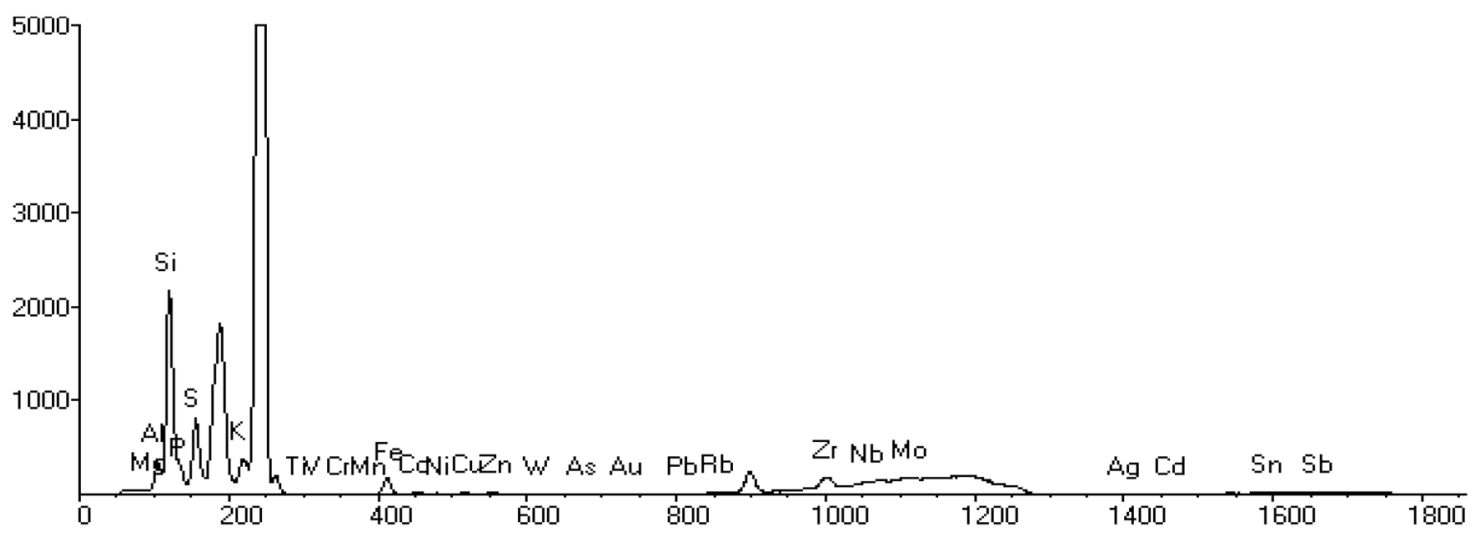

Fig. 2. XRF peaks for PU foam with dolomite.

of roughness and limited porosity. The degree of roughness and porosity are helpful features that promotes bonding of the particles with the matrix. Luong et al. [24] dispersed $\mathrm{SiC}$ and $\mathrm{Al}_{2} \mathrm{O}_{3}$ in polyurethane foam and observed similar trend in structure. The authors further observed existing cracks in the matrix very close to the particle-matrix interface.

\subsection{XRF analysis filled and unfilled polyurethane foam}

The results of the XRF for both dolomite and kaolin filled polyurethane foam is shown in Tables 1 and 2 and Figures 2 and 3 , respectively. It was discovered from the results that the predominant element in the dolomite filled polyurethane foam is calcium as shown in Table 1 and Figure 2 with the highest content of about $60 \%$ while other elements like silicon (about 6\%), sulphur (about $2 \%$ ) and aluminium (about $2 \%$ ) were also present in high proportions. On the other hand, silicon (25\%) and aluminium $(23 \%)$ were the elements that predominate the kaolin filled polyurethane foam as shown in Table 2 and Figure 3. Other elements like sulphur (2\%), calcium $(2 \%)$, iron $(1 \%)$ and tin $(1 \%)$ were present in high proportions compared to the trace elements. These elemental constituents will contributes to the behavour of the materials in service. 
Table 1. XRF result for PU foam with dolomite.

\begin{tabular}{llc}
\hline Element & Intensity & Content $(\%)$ \\
\hline $\mathrm{Al}$ & 0.0087 & 2.4047 \\
$\mathrm{Si}$ & 0.0574 & 5.7886 \\
$\mathrm{P}$ & 0.0076 & 0.3583 \\
$\mathrm{~S}$ & 0.0267 & 2.4170 \\
$\mathrm{Ca}$ & 0.6066 & 59.4877 \\
$\mathrm{~V}$ & 0.0000 & 0.0006 \\
$\mathrm{Mn}$ & 0.0002 & 0.0100 \\
$\mathrm{Co}$ & 0.0002 & 0.0020 \\
$\mathrm{Fe}$ & 0.0052 & 0.5791 \\
$\mathrm{Ni}$ & 0.0003 & 0.0146 \\
$\mathrm{Cu}$ & 0.0006 & 0.0126 \\
$\mathrm{Zn}$ & 0.0009 & 0.0280 \\
$\mathrm{~Pb}$ & 0.0001 & 0.0004 \\
$\mathrm{Au}$ & 0.0000 & 0.0168 \\
$\mathrm{Ag}$ & 0.0000 & 0.0001 \\
$\mathrm{Nb}$ & 0.0001 & 0.0003 \\
$\mathrm{Mo}$ & 0.0017 & 0.2237 \\
$\mathrm{Cd}$ & 0.0000 & 0.0000 \\
$\mathrm{Sn}$ & 0.0021 & 0.3760 \\
$\mathrm{Sb}$ & 0.0033 & 0.4103 \\
\hline
\end{tabular}

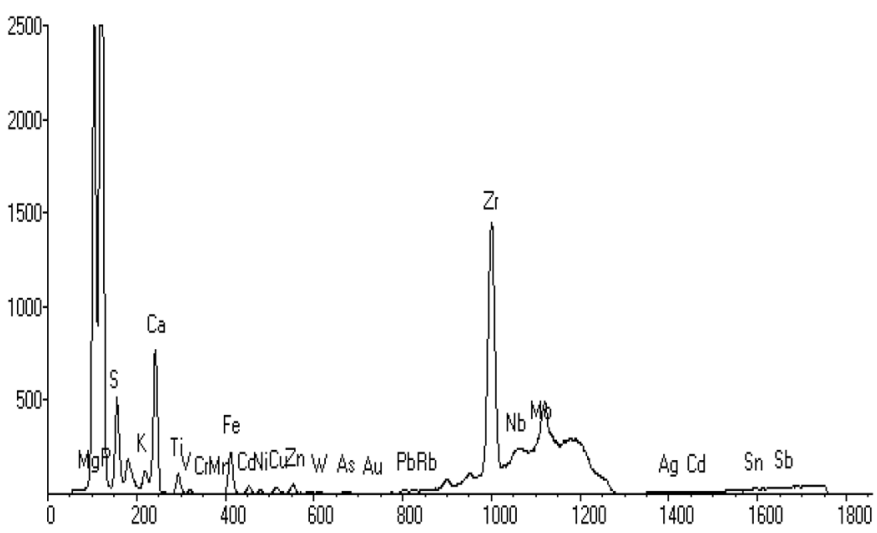

Fig. 3. XRF peaks for PU foam with kaolin.

\subsection{FTIR spectrum analysis filled and unfilled polyurethane foam}

The changes in composition and chemical functional groups in the dolomite/kaolin filled polyurethane foam was examined using FT-IR measurement. Figure 4 depicts the FT-IR spectra of the (a) unfilled polyurethane foam, (b) polyurethane foam filled with dolomite particles and (c) polyurethane foam filled with kaolin particles with significant functional groups labeled for clearness. The polyurethane foam without fillers (Fig. 4a; Tab. 3) revealed two $\mathrm{O}-\mathrm{H}$ groups responsible for the stretching vibration and stretching at 3098 and $2910 \mathrm{~cm}^{-1}$ respectively. The foam also shows a clear $\mathrm{C}-\mathrm{O}-\mathrm{C}$ peak at $1099 \mathrm{~cm}^{-1}$ with
Table 2. XRF result for PU foam with kaolin.

\begin{tabular}{llc}
\hline Element & Intensity & Content $(\%)$ \\
\hline $\mathrm{Al}$ & 0.1151 & 23.0588 \\
$\mathrm{Si}$ & 0.2185 & 25.3111 \\
$\mathrm{P}$ & 0.0036 & 0.1699 \\
$\mathrm{~S}$ & 0.0293 & 2.7782 \\
$\mathrm{~K}$ & 0.0031 & 0.2435 \\
$\mathrm{Ca}$ & 0.0388 & 2.7356 \\
$\mathrm{Ti}$ & 0.0054 & 0.9457 \\
$\mathrm{~V}$ & 0.0002 & 0.0107 \\
$\mathrm{Mn}$ & 0.0003 & 0.0128 \\
$\mathrm{Co}$ & 0.0003 & 0.0073 \\
$\mathrm{Fe}$ & 0.0126 & 1.2804 \\
$\mathrm{Ni}$ & 0.0012 & 0.0684 \\
$\mathrm{Cu}$ & 0.0022 & 0.0580 \\
$\mathrm{Zn}$ & 0.0031 & 0.1067 \\
$\mathrm{As}$ & 0.0008 & 0.0000 \\
$\mathrm{~Pb}$ & 0.0005 & 0.0163 \\
$\mathrm{~W}$ & 0.0002 & 0.0379 \\
$\mathrm{Au}$ & 0.0000 & 0.0195 \\
$\mathrm{Rb}$ & 0.0001 & 0.0005 \\
$\mathrm{Nb}$ & 0.0039 & 0.0434 \\
$\mathrm{Mo}$ & 0.0040 & 0.1745 \\
$\mathrm{Sn}$ & 0.0067 & 1.2461 \\
\hline & &
\end{tabular}

chain extenders consisting of the sulfonic groups. The sulfonic groups $\mathrm{S}-\mathrm{H}, \mathrm{S}=\mathrm{O}$ and $\mathrm{O}-\mathrm{S}-\mathrm{O}$ peaks appear at $\sim 1100,1398$ and $1050 \mathrm{~cm}^{-1}$ respectively with the $\mathrm{O}-\mathrm{S}-\mathrm{O}$ peak partially overlapping the $\mathrm{C}-\mathrm{O}-\mathrm{C}$ band. The urethane carbonyl peaks and $\mathrm{H}-\mathrm{NH}$ band also appeared with different intensities as reported in Table 3. The $-\mathrm{CH}$ bending vibrations due to substitution groups in alkenes and aromatics also appeared at $926 \mathrm{~cm}^{-1}$. The different peaks that appeared in the unfilled foam is an indication that both functional and sulfonic acid groups were successfully integrated into the polyurethane backbone. It is clearly observed that the addition of dolomite and kaolin as presented in Figure $4 \mathrm{~b}$ and c causes a change in modification of the absorption peaks. The sulfonic acid groups present in the unfilled polyurethane foam were observed to be absent in the dolomite/kaolin filled polyurethane foam. The degradation of the sulfonic acid groups could be related to the high content of Silica and calcium in the kaolin and dolomite respectively which promoted the appearance of $\mathrm{Si}-\mathrm{O}$ stretching vibration band.

\subsection{Mechanical properties of the polyurethane foams}

\subsubsection{Hardness of the polyurethane foam}

Comparative investigation of the hardness properties of the dolomite and kaolin based polyurethane were as shown in Figure 5 with the control sample. It is observed that the 

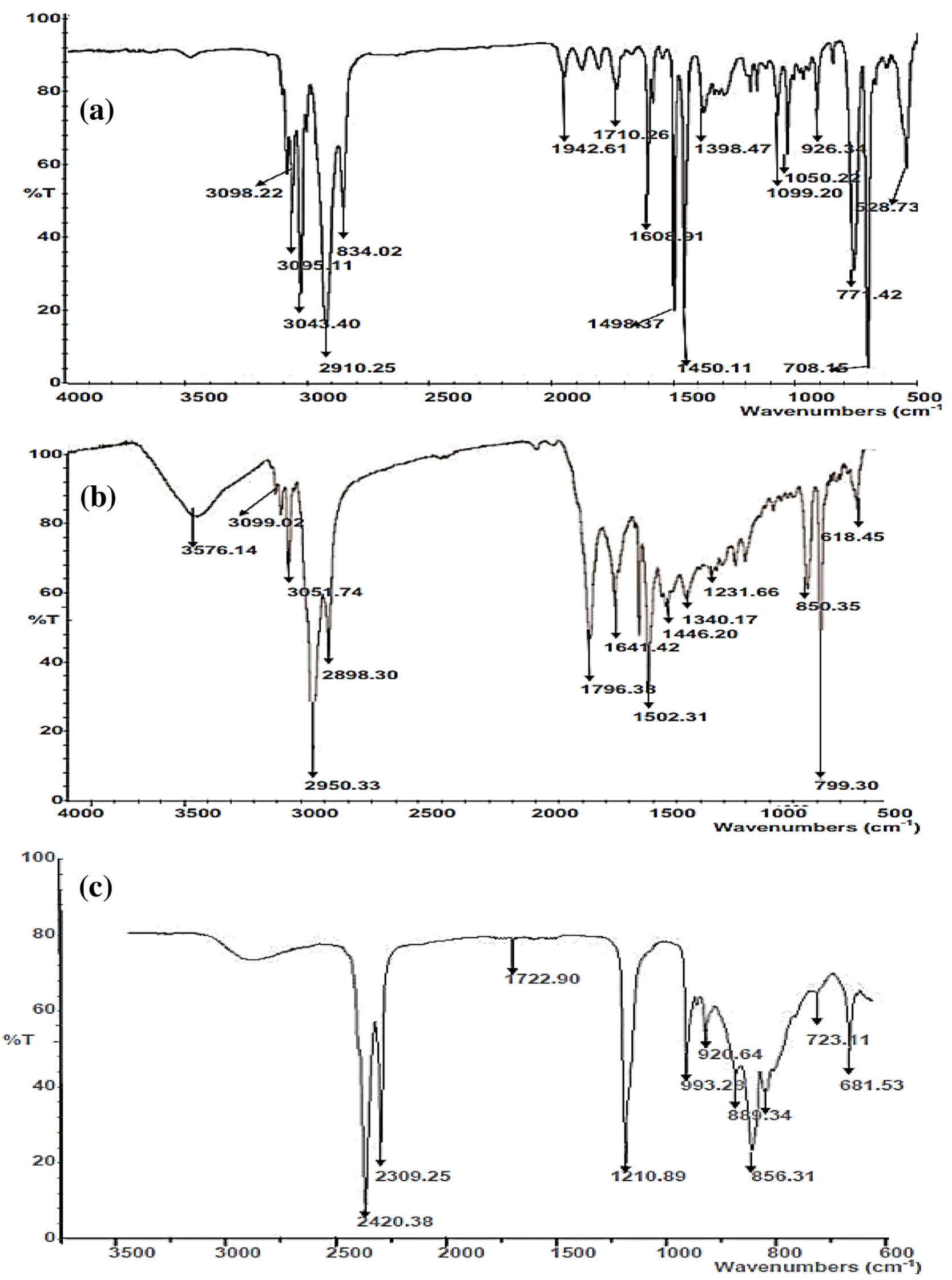

Fig. 4. FTIR spectrum for (a) unfilled polyurethane foam, (b) polyurethane foam filled with dolomite particles and (c) polyurethane foam filled with kaolin particles. 
Table 3. FTIR spectrum values for unfilled PU foam.

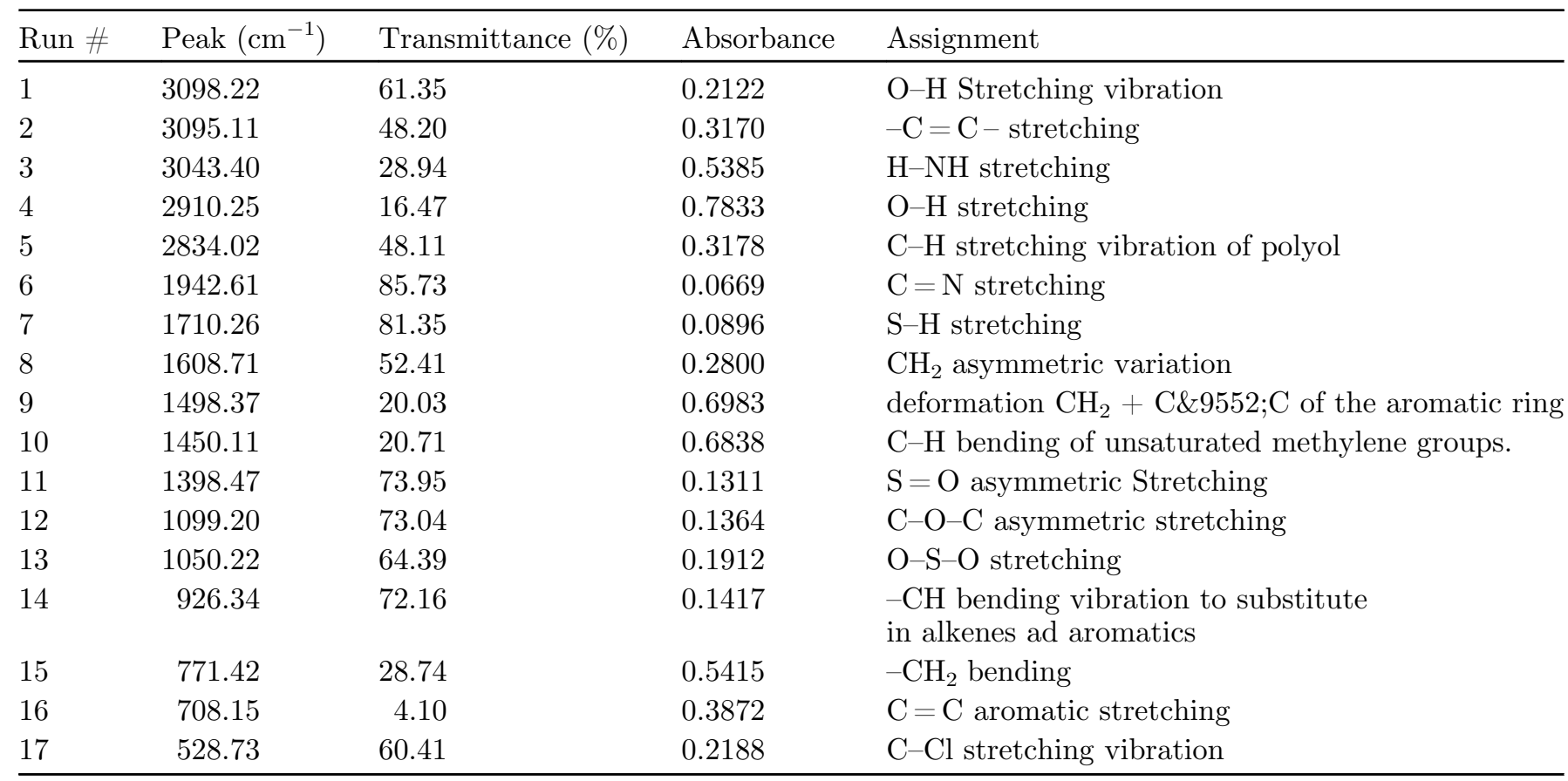

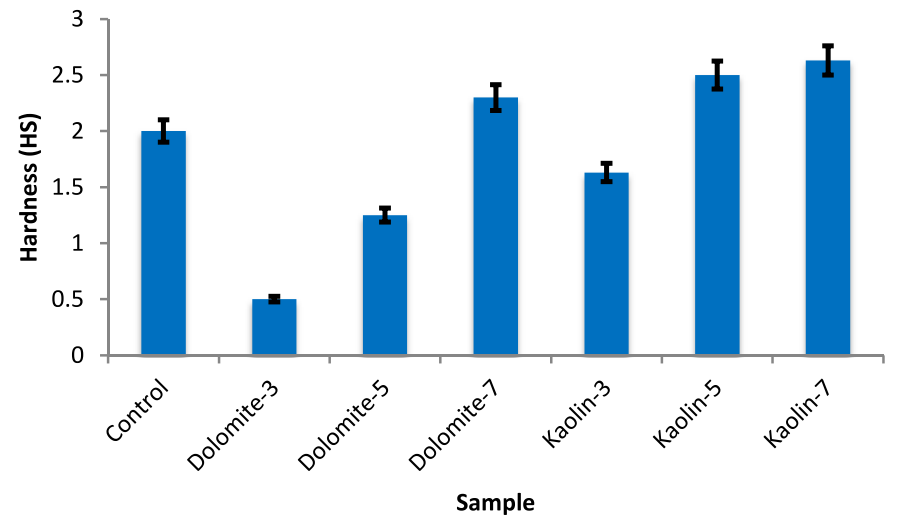

Fig. 5. Hardness property of the dolomite and kaoline filled polyurethane foam.

hardness increases as the filler contents increases from 3 to 7 wt.\%. Improved hardness was achieved with the addition of both fillers, however, the result revealed that kaolin filled foams had higher hardness than dolomite. Hence, maximum enhancement was achieved when $7 \mathrm{wt} \%$ kaolin was added to the polyurethane with a value of $2.63 \mathrm{HS}$ compared to the value from dolomite at the same filler content which has a value of 2.3 HS. The higher hardness values observed in the kaolin based polyurethane foam may be attributed to the presence of more elemental constituents in kaolin than dolomite considering the dominating elements. The improvement achieved was about $32 \%$ compared to the control sample. Hence, kaolin can be added in higher proportion to polyurethane foam in order

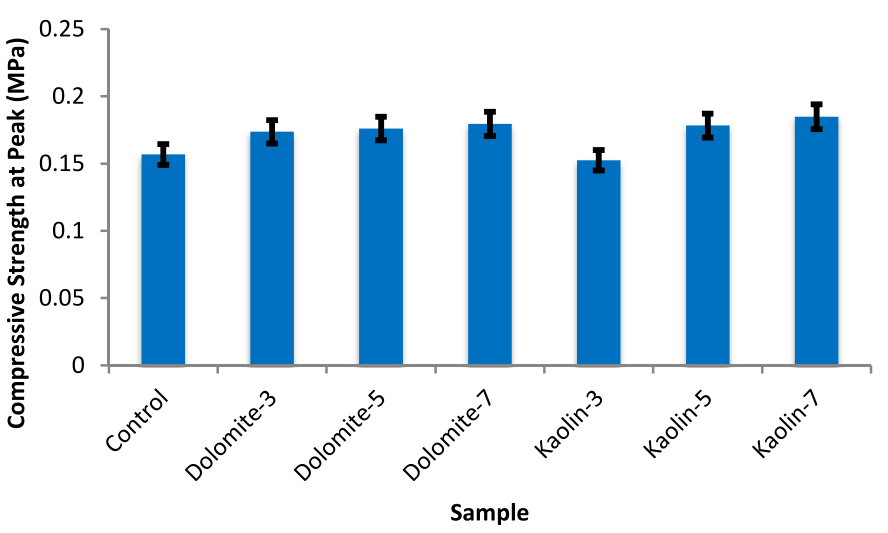

Fig. 6. Compressive strength at peak of the dolomite and kaoline filled polyurethane foam.

to achieve improved hardness. This will be very useful in developing PU foam for use on an industrial scale in the construction and packaging industries.

\subsubsection{Compressive strength of the polyurethane foam}

Results of the compressive strength at peak for the reinforced and unreinforced polyurethane foam were as shown in Figure 6. Similar to Figure 5, addition of the fillers brought about enhancement in the compreissive strength as the content increases from 3 to $7 \mathrm{wt} . \%$. While all the samples of the kaolin and dolomite filled PU have improved strength than the unfilled PU, the 3 wt.\% kaolin filled PU is observed to have a reduced strength. However, optimum 
value was obtained in the 7 wt.\% kaolin filled PU with a value of about $0.185 \mathrm{MPa}$ compared to $0.180 \mathrm{MPa}$ for the dolomite filled PU with the same filler content. The result obtained shows that the filled PU has improved compressive strength when compared to the unfilled PU with a difference of about $18 \%$ enhancement. The variation of compressive strain at peak of the filled polyurethane foam is presented in Figure 7. The addition of dolomite/kaolin to the polyurethane reduced the compressive strain but increased with filler content.

\subsubsection{Flexural strength of the polyurethane foam}

Figures 8 and 9 depicts the flexural strength and strain at peak of the dolomite/kaolin filled polyurethane foam respectively. The flexural strength of the polyurethane foam without dolomite/kaolin addition is about $0.39 \mathrm{MPa}$. The addition of $3 \mathrm{wt} . \%$ of dolomite and kaolin increased the flexural strength of the foam to about 0.42 and $0.45 \mathrm{MPa}$ respectively. The addition of dolomite and kaolin particles beyond $3 \mathrm{wt} . \%$ decreased the strength below that of the polyurethane foam. This implies that, for applications that

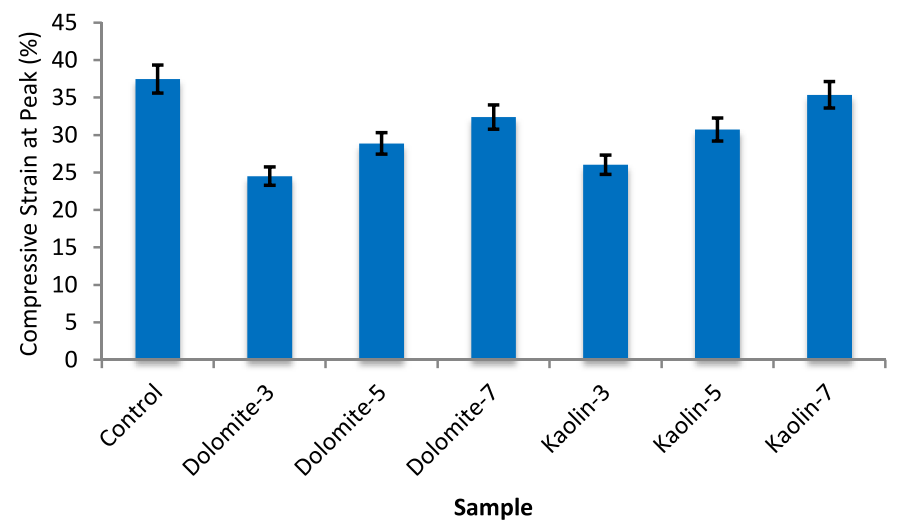

Fig. 7. Compressive strain at peak of the dolomite and kaoline filled polyurethane foam. require utmost flexural strength, a polyurethane foam with fillers above 3 wt.\% cannot be utilized. The flexural strength of both the dolomite and kaolin filled polyurethane foam decrease gradually with increasing filler

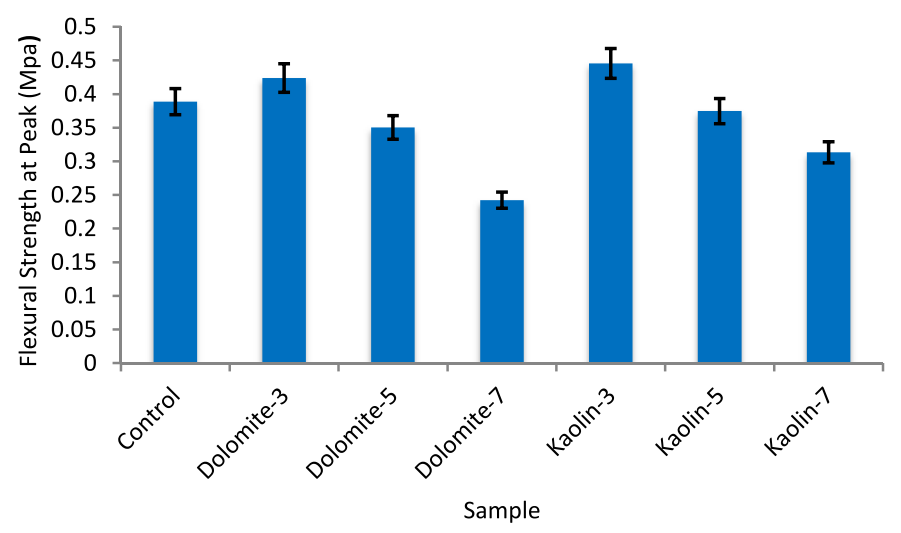

Fig. 8. Flexural strength at peak of the dolomite and kaoline filled polyurethane foam.

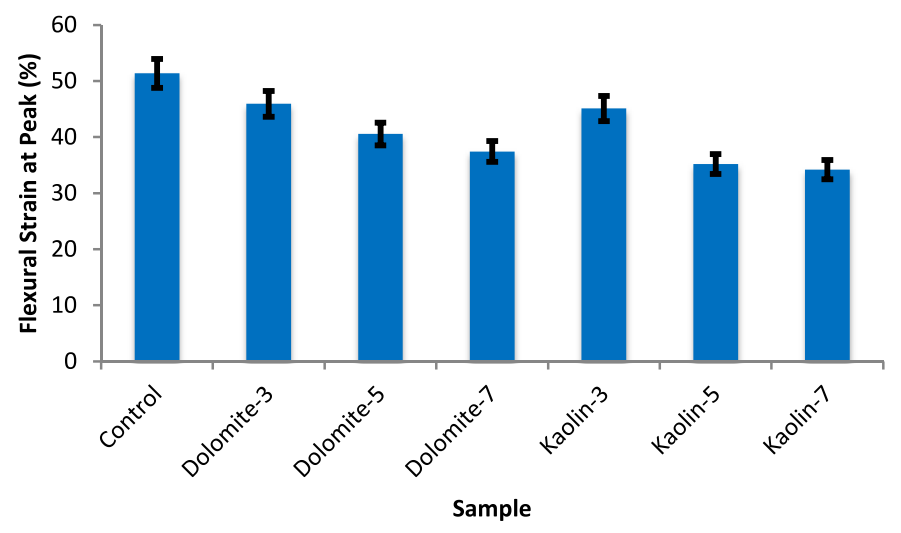

Fig. 9. Flexural strain at peak of the dolomite and kaoline filled polyurethane foam.

Table 4. FTIR spectra values for dolomite filled polyurethane foam.

\begin{tabular}{lllll}
\hline Run \# & Peak $\left(\mathrm{cm}^{-1}\right)$ & Transmittance $(\%)$ & Absorbance & Assignment \\
\hline 1 & 3576.14 & 83.71 & 0.0772 & O-H asymmetrical Stretching vibration \\
2 & 3099.02 & 88.26 & 0.0542 & N-H Stretching \\
3 & 3051.74 & 68.04 & 0.1672 & $-\mathrm{C}=\mathrm{C}-$ stretching \\
4 & 2950.33 & 28.31 & 0.5481 & Asymmetrical stretching vibrations of CH groups \\
5 & 2898.30 & 44.62 & 0.3505 & Symmetric stretching vibrations of CH groups \\
6 & 1796.38 & 48.15 & 0.3174 & $\mathrm{C}=$ O stretching vibration \\
7 & 1641.42 & 56.84 & 0.2454 & O-H asymmetrical bending vibration \\
8 & 1446.20 & 58.21 & 0.2350 & C-H bending of unsaturated methylene groups. \\
9 & 1340.17 & 60.03 & 0.2216 & deformation CH H $_{2}+$ C\&9552; of the aromatic ring \\
10 & 1231.66 & 68.24 & 0.1660 & Si-O vibration \\
11 & 850.35 & 60.14 & 0.2208 & C-O-C symmetric stretching \\
12 & 618.45 & 84.71 & 0.0721 & C-Cl stretching vibration \\
\hline
\end{tabular}


Table 5. FTIR spectrum values for kaolin filled polyurethane foam.

\begin{tabular}{lccll}
\hline Run \# & Peak $\left(\mathrm{cm}^{-1}\right)$ & $\begin{array}{l}\text { Transmittance } \\
(\%)\end{array}$ & Absorbance & Assignment \\
\hline 1 & 2420.38 & 8.23 & 1.0846 & O-H Stretching vibration \\
2 & 2309.25 & 24.11 & 0.6178 & N-H Stretching \\
3 & 1722.90 & 80.20 & 0.0958 & -C-O stretching \\
4 & 1210.89 & 28.10 & 0.5513 & Symmetric (Si-O) normal to the plane stretching \\
5 & 993.28 & 48.77 & 0.3119 & Symmetric (Si-O) planar stretching \\
6 & 920.64 & 60.03 & 0.2216 & O-H deformation \\
7 & 889.34 & 44.18 & 0.3548 & Al-Mg-OH deformations \\
8 & 856.31 & 24.96 & 0.6028 & O-H stretching of quartz \\
9 & 723.11 & 64.78 & 0.1886 & Al-O-Si inner surface vibration \\
10 & 681.53 & 53.95 & 0.2680 & Si-O stretching vibration \\
\hline
\end{tabular}

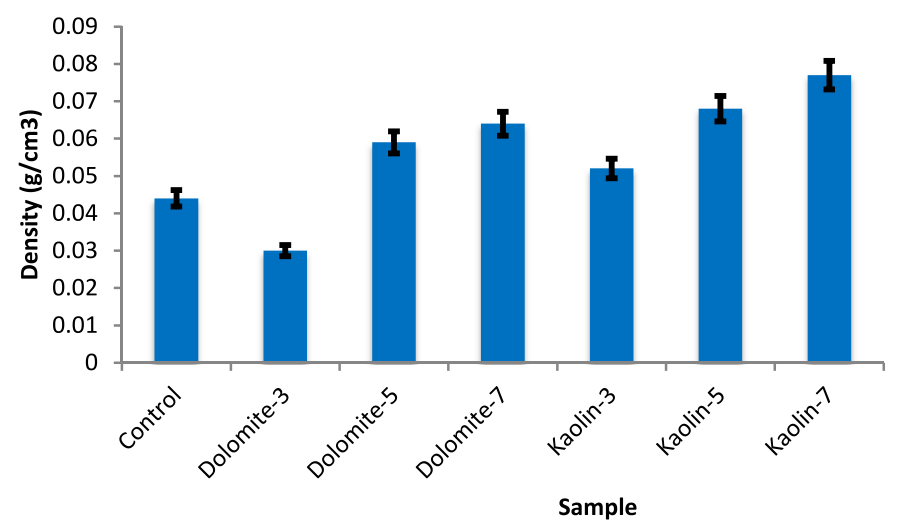

Fig. 10. Densities the dolomite and kaoline filled polyurethane foam.

content. It is also worthy to note that the flexural strength of the kaolin filled polyurethane foam is higher than that of the dolomite with the same filler content. The improved flexural strength of the filled polyurethane with $3 \mathrm{wt} . \%$ could be attributed to the moderate surface modification of foam, which increase the interfacial combination between the foam matrix and filler. In addition, the flexural strain at peak (Fig. 9) of the filled polyurethane foams varies in the range of 30 to $50 \%$. The addition of dolomite/kaolin to the polyurethane foam do not enhance the elongation property of the foam.

\subsubsection{Density of the polyurethane foam}

The effect of dolomite and kaolin on the density of the polyurethane foam is presented in Figure 10. The result generally shows an increase in density with the addition of kaolin and dolomite except for the foam filled with $3 \mathrm{wt} . \%$ dolomite. The reduction in density with $3 \mathrm{wt} . \%$ dolomite is rather complex and difficult to thoroughly understand. Thus, it is necessary to investigate the reaction pathways between the filler component and isocyanate. Such experimentation is under consideration. The densities were also observed to increase with filler content from 3 to $7 \mathrm{wt} . \%$. It is imperative to state that with increase of filler content the quantity of urethane reaction heat that is absorbed by the filler increases thus causing the increase of polyurethane foam density. The increase in density could also be attributed to the higher densities of kaolin and dolomite $\left(2.65\right.$ and $2.84 \mathrm{~g} / \mathrm{cm}^{3}$ respectively) compared to the Polyurethane form $\left(1.26 \mathrm{~g} / \mathrm{cm}^{3}\right)$.

\section{Conclusion}

This study investigates the influence of varying content of kaolin and dolomite particle addition on the physical, mechanical, and chemical properties of polyurethane foam. The following conclusions were drawn from this study:

- The presence of the fillers in the foam showed a rupture in the structure of the foams with the cells having similar arrangements.

- The predominant element in the dolomite filled polyurethane foam is calcium while silicon and aluminum were the elements that predominate the kaolin filled polyurethane foam.

- The addition of dolomite and kaolin causes a change in modification of the absorption peaks with the degradation of the sulfonic acid groups.

- The addition of dolomite and kaolin increased the density and enhanced the properties of hardness, flexural and compressive strengths of the polyurethane foam.

- Based on these results, the filled polyurethane foams can potentially be used on an industrial scale in the construction and packaging industries.

Acknowledgement. The authors would like to appreciate the Tertiary Education Trust Fund (TETFund) of Nigeria for funding this research. 


\section{References}

1. R.S. Malani, V.C. Malshe, B.N. Thorat, Polyols and polyurethanes from renewable sources: past, present and future - part 1: vegetable oils and lignocellulosic biomass, J. Coat. Technol. Res. (2021) 1-22

2. C. Ligoure, M. Cloitre, C. Le Chatelier, F. Monti, L. Leibler, Making polyurethane foams from microemulsions, Polymer 46 (2005) 6402-6410

3. S. Członka, A. Strąkowska, K. Strzelec, A. AdamusWłodarczyk, A. Kairyte, S. Vaitkus, Composites of rigid polyurethane foams reinforced with POSS, Polymers 11 (2019) 336

4. S. Suleman, S.M. Khan, T. Jameel, W. Aleem, M. Shafiq, Synthesis and characterization of flexible and rigid polyurethane foam, Asian J. Appl. Sci. 2 (2014) 701-710

5. I.O. Oladele, J.O. Ajileye, S.R. Oke, O.O. Daramola, O.A. Adewumi, Thermal and water absorption properties of bio-synthetic hybrid reinforced polypropylene composites, Mater. Today 38 (2021) 994-998

6. S.L. Everitt, O.G. Harlen, H.J. Wilson, Bubble growth in a two-dimensional viscoelastic foam, J. Non-Newtonian Fluid Mech. 137 (2006) 46-59

7. S. Tan, T. Abraham, D. Ference, C.W. Macosko, Rigid polyurethane foams from a soybean oil-based polyol, Polymer 52 (2011) 2840-2846

8. K.K. Alaneme, S.R. Oke, J.A. Omotoyinbo, Water absorption characteristics of polyester matrix composites reinforced with oil palm ash and oil palm fibre, Usak Univ. J. Mater. Sci. 2 (2013) 109-120

9. I.O. Oladele, Effect of bagasse fibre reinforcement on the mechanical properties of polyester composites, J. Assoc. Prof. Eng. Trinidad Tobago 42 (2014) 12-15

10. S. Matsumura, Y. Soeda, K. Toshima, Perspectives for synthesis and production of polyurethanes and related polymers by enzymes directed toward green and sustainable chemistry, Appl. Microbiol. Biotechnol. 70 (2006) 12-20

11. M. Urgun-Demirtas, D. Singh, K. Pagilla, Laboratory investigation of biodegradability of a polyurethane foam under anaerobic conditions, Polym. Degrad. Stab. 92 (2007) $1599-1610$

12. D. Yan, L. Xu, C. Chen, J. Tang, X. Ji, Z. Li, Enhanced mechanical and thermal properties of rigid polyurethane foam composites containing graphene nanosheets and carbon nanotubes, Polym. Int. 61 (2012) 1107-1114

13. T. Widya, C.W. Macosko, Nanoclay-modified rigid polyurethane foam, J. Macromol. Sci. B 44 (2005) 897-908

14. B.H.S. Thimmappa, A. Karthik, B. Shivamurthy, N. Naik, S. Sharma, D.K. Shetty, Recent advances in carbon-based polymer composites for effective electromagnetic interference (Emi) shielding, Int. J. Adv. Sci. Technol. 29 (2020) 6207-6234

15. L. Verdolotti, M.R. Di Caprio, M. Lavorgna, G.G. Buonocore, Polyurethane nanocomposite foams: Correlation between nanofillers, porous morphology, and structural and functional properties, In Polyurethane Polymers. Elsevier (2017) pp. 277-310

16. B. Czuprynski, J. Paciorek-Sadowska, J. Liszkowska, Modifications of the rigid polyurethane-polyisocyanurate foams, J. Appl. Polym. Sci. 100 (2006) 2020-2029

17. J. Liszkowska, B. Czuprynski, J. Paciorek-Sadowska, Thermal properties of polyurethane-polyisocyanurate (PUR-PIR) foams modified with tris (5-hydroxypenthyl) citrate, J. Adv. Chem. Eng. 6 (2016)

18. M.C. Saha, M.E. Kabir, S. Jeelani, Enhancement in thermal and mechanical properties of polyurethane foam infused with nanoparticles, Mater. Sci. Eng. A 479 (2008) 213-222

19. U.S.T.A. Nazim, Effects of kaolin additions on thermal behaviors of rigid polyurethane foams, J. Therm. Eng. 5 (2019) 70-76

20. M.F. Sonnenschein, R. Prange, A.K. Schrock, Mechanism for compression set of TDI polyurethane foams, Polymer 48 (2007) 616-623

21. ASTM D2240-00 Standard Test Methods for Determining the hardness of soft and hard plastics, North America, 2000

22. L. Zhang, X. Ding, Y. Ou, Properties of rigid polyurethane foams prepared with synthesized PIPA polyol, Am. J. Chem. Appl. 1 (2014) 7-14

23. A.S.T.M Standard, D790-03. Test methods for flexural properties of unreinforced and reinforced plastics and electrical insulating materials, ASTM International, West Conshohocken (PA), 2003

24. D.D. Luong, V.C. Shunmugasamy, O.M. Strbik, III., N. Gupta, High strain rate compressive behavior of polyurethane resin and polyurethane $/ \mathrm{Al}_{2} \mathrm{O}_{3}$ hollow sphere syntactic foams, J. Compos. (2014)

Cite this article as: Joseph Ajibade Omotoyinbo, Isiaka Oluwole Oladele, Jamiu Mosebolatan Jabar, Joseph Olatunde Borode, Kenneth Kanayo Alaneme, Akeem Damilola Akinwekomi, Samuel Ranti Oke, Taiwo Fisayo Omotosho, Lawrence Ojo Saliu, Comparative investigation of the influence of kaolin and dolomite on the properties of polyurethane foam, Manufacturing Rev. 8, 27 $(2021)$ 